ISBN 978-81-933894-1-6

2017 International Conference on Studies in Business Management, Law and Education

(SBMLE-17)

Kyoto (Japan) April 20-21, 2017

\title{
Using Drama Technique to Engage University Students in Course Work
}

\author{
Rubayat Kabir \\ East West University, Dhaka, Bangladesh.
}

\begin{abstract}
Engaging students in class activity is a relatively complex task. It has been a concern for several academicians and researchers. Tremendous efforts are usually put forward to establish interest in the activities designed for the course. This paper explores related studies on the application of drama technique to enhance class activity. It tries to find out whether dramatization can be used to encourage University student's coursework involvement.

Students of Sociology were assigned to conduct dramas as a part of their coursework. The participants ranged from $3^{\text {rd }}-12^{\text {th }}$ semester. A total number of 40 participants got enrolled in the course out of which 38 of them took part in the given work. There were 10 male and 30 female students including 2 group leaders. An equal number of participants were divided into two groups and each group had to enact a drama. The participants along with their group representatives were responsible from initial formation of groups to completion of the play. After the event was over, students provided feedback regarding their experience. Subsequent to a window period of 3 months, these students again provided feedback on their activity.

It was thus noted that the exercise aided in enhancing students' self-esteem. Their outlook towards taking part in similar classroom activities, even for other courses was more confirmatory. Most of the participant's perception regarding their ability to involve in like activities was more positive. Although, most of the students reported more constructively, yet there were some disliked factors mentioned for further improvisation.
\end{abstract}

Keywords: Student engagement, Experiential learning, Dramatization, Self- esteem.

\section{Introduction}

Experiential Learning Theory (ELT) can be traced back in the significant works of Dewey, Lewin, Piaget, Jung, Rogers and few significant others [1], [2]. The reason behind the term 'experiential' was primarily because the theory combines philosophical pragmatism, social psychology and cognitive-developmental perspective on learning [1]. Various terms have been used to label this learning process. Dewey, in his article discussed this concept as "learning by doing," while Wolfe and Byrne used the term "experienced-based learning", also the term "trial and error" is used to explain this inductive learning processes (as cited in [3], [4].

This is also the reason to view this approach of learning as holistic in nature. It is witnessed that Experiential Learning can significantly increase students' confidence regarding the knowledge of the subject [5]. It involves interactions with all our senses, i.e. to listen, to see, to touch, to taste and to smell [6]. The definition of technical education as cited in "reference [7] states the reconstruction or reorganization of experience that adds to the meaning of that experience and which increases ability to direct the course of subsequent experience".

Experience gained can be both active and passive. The meaning of active in this case refers to the participants understanding and taking control in receiving information. Whereas, the passive side is to an extent is beyond the control of the participant [8]. A large number of students pursue their degree in higher education by considering themselves as passive recipients of what they are taught. However, being an active participant 
of the learning process where the students are in charge for their own experiences can largely improve their learning capabilities [9].

Learning is not limited to the classroom. Nevertheless, when students are asked about their recent learning, the responses are usually related to what they learn in lectures. Deriving appropriate life learning lessons from the past and then later constructing a reflection based on those lessons is known as experiential learning [10].

Highlighting the concept of Reference [11], "Education must be conceived as a continuing reconstruction of experience". Hence, learning is better realized by focusing more on the process instead of the results. Furthermore, learning in higher education can be made more effective through teaching methods that allow the learning capabilities of students to be nurtured and enriched. This also involves receiving appropriate evaluations on the learning endeavors of the students. Moreover, the use of arts in management education, despite being a relatively new concept has undeniably received considerable recognition [12].

As stated by Reference [13], incorporating drama within the learning process, students are allowed to delve into both factual knowledge and content concepts while improving their learning abilities. As a result, both linear and holistic drama has the power to influence and enhance learning abilities of the students as they reflect upon their individual and unique contributions along with what the drama content teaches.

Reference [14] iterates that these drama sessions engage highly energetic students in more lively discussions that later enable them to link their experiences to management theory in their writing assessments. Moreover, interactive drama can thus create memorable management classroom sessions for students that help achieve general learning objectives such as increasing student knowledge and students' as suggested by many evidences.

Meanwhile, Reference [15] explores applied Drama as a teaching approach in Higher Education learning spaces. The paper then concludes the use of Applied Drama techniques and skills in crafting teaching approaches. It can be fruitful in engaging the $21^{\text {st }}$ century University students particularly in the area of Humanities and Social Sciences.

Reference [16] takes into account the evaluation of drama-in-education in programs which can enhance the English oral communication skills of several potential teachers. The study is based on primary data collected from personal interviews as well as observations of presentations made by trainee teacher. The findings suggest that use of drama as a teaching method largely improves the English oral communication skills of teachers, many of whom are all eager to use drama as a teaching technique that helps boost their skills and confidence.

\section{Method and Procedure}

Undergraduate level students in a University situated in the capital of Bangladesh, organized and took part in Drama as assignment work. The course code was SOC203 i.e. Social group and Social development. The course was designed for undergraduate students having major in Sociology. The duration of the course which falls in the tri-semester system, meaning four allotted months for each semester; approximately about 14-15 weeks. The enrolled participants ranged from $3^{\text {rd }}-12^{\text {th }}$ semester. The major component of the course was to understand the effectiveness and process of group work to deal with complex social issues. Understanding group work concepts without actually getting involved in the process may seem vague to the students. With this objective, it was premeditated that involving students in Drama would serve the purpose of understanding group work process by experiencing it. Additionally, they would be able to apply critical thinking on the existing social issues. The time duration to complete the activity was about 6 weeks.

A total number of 40 participants got enrolled in the course out of which 38 of them took part in the given work. There were 10 male and 30 female students altogether. Though, 8 male and 30 female students took part. An equal number of participants were divided into two groups. In the preliminary stage, two students volunteered to be group representatives. This was done on the basis of participant's willingness to lead. The participants were put in each group on a random basis. The division of members in each group was ensured by pairing 2 members together and assigning pseudo names for each that was designated by them. Each group 
leaders took their turns to choose the name without knowing whom they were picking. After all the 36 members were put into the respective groups, they were then asked to explore the topic on which they could enact the drama.

Both the groups came up with at least 3 topic out of which 1 was selected. The group leaders were responsible to communicate every major step to the course instructor. After the topic selection, they had to prepare drama script. Initially the leaders faced few glitches to bring all the group members together. However, as time approached and the course instructor communicated extensively to boost participation. It was seen that, members progressively indulged into the process. The script went through a lot of trial and error and successively every one ensured either small of big role in the activity. Group leader along with few supportive members were also responsible for creating group contracts to illustrate their roles and responsibilities. To ensure participation, the course instructor very seldom along with the group leaders went to the rehearsals for a very short time as a passive audience.

The members along with their group representatives were responsible from initial formation of groups to completion of the play. The group leaders were further in charge to invite students and teachers to attend the play. On the final day, fellow members took their turns to welcome the audience, host the program, enact in the play and finally conclude the session. After the program concluded, participants in their enthusiasm of achievement provided informal feedback regarding their activity. Ensuing the window period of 3 months, these students again provided feedback. To avoid biasness the participants anonymously provided feedback to their group leaders and one of its associate members instead of the researcher.

\section{Content of the Drama}

Group A chose the topic that portrayed general behavior towards the lower section of the society. The script of the play was more culture centric. The motive was to create alertness on our inappropriate behavior towards others. The drama had 5 segments with 4 leading characters. Two chief teenage characters depicted rude behavior in different situations with their household worker. Later, they recognized their mistakes when they received similar treatment by others. Another key character showed ignorant behavior with an old mendicant who later realizes the agony when he had to starve. Another character got into physical fight with a rickshaw puller for a trivial reason on fare related issue. But later, the same person in another situation helped him to reach the destination without actually taking money. Finally, all these characters concluded by stating that they would never behave the same way and rethink about their approach.

On the other hand, Group B selected the topic 'harassment of women in different sectors of the society'. They presented a scene related to women working in advertising agency. The next segment offered to show gender discernment in the aspect of relationship, i.e. how a typecast boy treats a girl when other attractive women are around. The later section presented that how in the educational sector students perceive male faculties as superior as compared to female faculties. And the last scene showed how ladies in the prostitution sector are treated ignorantly without considering their emotions.

\section{Discussion}

The level of participation by all members in the respective groups was remarkable. Judging from their active participation, it was clear that they were very confident in their approach and enjoyed audience feedback. It was observed from initial group formation, there were feelings of incompetency of getting involved in the task. During the process, few of the participants approached the course instructor to change the type of task. Nevertheless, they were asked to carry on.

After finishing the task, the partakers were extremely rejoiced for its successful completion. Out of the total, around 68 percent of them loomed the instructor, either in groups or individually to express their gratitude for giving the opportunity to take part in the activity. Formal feedback was again taken from the group members after 3 months. Among them 84 percent voluntarily provided feedback and the other 16 percent did not respond 
to the queries. There were two sections in the questionnaire. One section was related to their personal experience on the task and the other section was regarding recommendation on the activity.

TABLE 1: FEEDBACK ON THE ACTIVITY

\begin{tabular}{ccc}
\hline \hline Comments on assignment & Number of responses & Percentage of responses (\%) \\
\hline Experience Gained & 32 & 100 \\
Teamwork & 8 & 25 \\
Critical thinking & 18 & 56 \\
Performance & 15 & 47 \\
\hline \hline
\end{tabular}

Table 1 shows comments on the assignment. The feedback was categorized into experience gained, team related activities, critical thinking and performance. The percentages that are shown in the above table are rounded off to the nearest figure. Experience gained in general means their overall perception about the activity. All the respondents provided positive response. Some of them either mentioned that it was their first stage experience or the overall experience gained was good. Nearly, 25 percent mentioned positive response on team work related activities. These participants reported having moderately high degree of cohesiveness among the mates. Around 56 percent of them talked about the lessons from the activity and nearby 47 percent of them provided constructive feedback regarding their own performance which was more of building personal skills. It has been observed that group simulation exercises makes students more involved in the task and enhances critical thinking [17].

On the recommendation section nearly 54 percent participants proposed that they should be given more of the similar task; if possible this should be designed and applied for other courses as well. About 22 percent of them gave feedback on providing storyline and script in the future so that they could concentrate better on performance. All the others did not provide any suggestion, instead was appreciative about the task.

From both the analysis part, it was deducted that their attitude towards performing in drama as part of the course work was transformed. All these dimensions directed towards enhancing the participants self-esteem.

\section{Conclusion}

Drama can be employed in countless ways in the contemporary classrooms to actively engage students in course work. This could be applied to other subjects, especially in the courses that talks about group/team work and society related issues. As findings suggests, this technique could be used not only understand the course content, but also aid in the development of interpersonal communication and gain self-control. It promotes ones understanding of working with teams in the area of cooperation, cohesiveness and conflict. As this teaching/learning method is accepted by the students, engaging them in these similar kinds of simulation activities may prove to be beneficial. And as a matter of fact, better output can thus be achieved.

\section{Acknowledgements}

I am truly grateful to the students of SOC203: Social Group and Social Development, fall 2016, Department of Social Relation, East West University, who have actively participated and successfully completed the given task. I express my gratitude to Zaima Zabin and Sk. Fozilatunnesa Muna for assisting me with the survey. I am thankful to Prof. Bijoy P. Barua for his support towards the activity. I am obliged to Dr. Rafiqul Huda Chaudhury for his enormous encouragement to engage in research. Also my colleagues and mentors Dr. Parveen Haque, Ms. Touhida Taslima, Dr. Lutfun Nahar, Dr. Marzia Zaman Sultana, Mr. Sanaul Mondal, Mr. Shahriar Khandakar, Ms. Sifat-E-Sultana, Ms. Azrin Afrin, Dr. Anisur Rahman Khan and Dr. Fouzia Mannan for their guidance. And I appreciate the efforts of East West University for their support towards research activities. 


\section{References}

[1] D. A. Kolb, "Experiential learning: Experience as the source of learning and development." New Jersey: Prentice-Hall. 1984.

[2] M. Mccarthy, (2010). Experiential Learning Theory: From Theory To Practice. Journal of Business \& Economics Research (JBER), 8(5), pp. 131-139. doi:10.19030/jber.v8i5.725.

https://doi.org/10.19030/jber.v8i5.725

[3] J. W. Gentry, “WHAT IS EXPERIENTIAL LEARNING?" In Guide to business gaming and experiential learning. East Brunswick u.a.: Nichols u.a. 1990. pp. 9-20.

[4] F. Mollae and H. Rahnama, (2012). Experiential Education Contributing to Language Learning. International Journal of Humanities and Social Science, 2(21), pp. 268-279.

[5] H. LaVan and C. Carley, (1981). An Empirical Analysis of Experiential Learning for Learning Reinforcement," Developments in Business Simulation and Experiential Exercises, 8, pp. 214-217.

[6] D. A. Kolb and R. Fry, "Toward an applied theory of experiential learning." in C. Cooper (ed.), Theories of Group Process, London: John Wiley. 1975.

[7] J. Dewey, "Democracy and Education." An introduction to the philosophy of education (1966 Edn.), New York: Free Press. 1916.

[8] J. Dewey, “Experience and Education”, New York: Collier Books. 1938.

[9] A. Y. Kolb and D. A. Kolb, (2005). Learning Styles and Learning Spaces: Enhancing Experiential Learning in Higher Education. Academy of Management Learning \& Education, 4(2), pp. 193-212. doi:10.5465/amle.2005.17268566. https://doi.org/10.5465/AMLE.2005.17268566

[10] M. Barth, J. Godemann., M. Rieckmann and U. Stoltenberg, (2007). Developing key competencies for sustainable development in higher education. Int. J. Sustainab. Higher Educ., 8, pp. 416-430.

https://doi.org/10.1108/14676370710823582

[11] J. Dewey, (1897). My pedagogic creed. School Journal, 54, pp. 77-80.

[12] N. Nissley, 'Arts-based Learning in Management Education." In C. Wankel and B. DeFillippi, (Eds), Rethinking management education for the 21st century. New York: Information Age Pub. 2002, ch. 2, pp. 27-6.

[13] J. L. Smith and J. D. Herring, (1993). Using Drama In The Classroom. Reading Horizons, 33(5), pp. 6. Available http://scholarworks.wmich.edu/reading_horizons

[14] J. G. Boggs, A. E. Mickel and B. C. Holtom, (2007). Experiential Learning Through Interactive Drama: An Alternative To Student Role Plays. Journal of Management Education, 31(6), pp. 832-858. doi:10.1177/1052562906294952.

https://doi.org/10.1177/1052562906294952

[15] C. Moyo, (2015). Applied Drama and the Higher Education Learning Spaces: A Reflective Analysis. Journal of Education and Practic, 6(6), pp. 9-14.

[16] L. Athiemoolam, (2013). Using drama-in-education to Facilitate Active Participation and the Enhancement of Oral Communication Skills among First Year Pre-service Teachers. Scenario, 2013(2), pp. 22-36.

[17] D. Jaques, Learning in Groups: A Handbook for Improving Group Working. $3^{\text {rd }}$ Edn, Routledge Falmer, London, ISBN: 10:0749430915, pp. 320. 2000. 